\title{
A Study on the influence of country image on purchase intention of Chinese consumers based on Fishbein's model of reasoned action: Focused on USA, Germany, Japan and South Korea
}

\author{
(C) Higher Education Press and Springer-Verlag 2009
}

\begin{abstract}
This study finds that Chinese consumers' perception of country image can be divided into four dimensions: appraisal of the relationship with China, degree of country development, general product appraisal, and general people appraisal. The items in these four dimensions vary for different countries. The study incorporates country image into the Fishbein's model, and finds good fitness between the model and data, which suggests that the Fishbein's model has good generalizability and cross-culture adaptability. Results show that country image has no direct impact on purchase intention; instead, it impacts on consumers' purchase intention indirectly through the effects on functional appraisal and symbolic appraisal, brand attitude and subjective norm. The effect of country image on purchase intention varies for different products. Specifically, the effect of country image on purchase intention of apparel is greater than that of cell phone, and that on purchase intention of car is the lowest.

Translated from Nankai Guanli Pinglun 南开管理评论 (Nankai Business Review), 2008, 11(5): 40-49

LI Dongjin $(\triangle)$

School of Business, Nankai University, Tianjin 300071, China

E-mail: djli1280@163.com

AHN Jongseok

College of Economics and Business, Jeonju University, Jeonju 560-759, South Korea

E-mail: jsahn@jj.ac.kr

ZHOU Ronghai

School of Business, Nankai University, Tianjin 300071, China

E-mail: zhouronghai@gmail.com

WU Bo

School of Management, Anhui University of Technology, Ma'anshan 243002, China

E-mail: wubo2120061991@yahoo.com.cn
\end{abstract}


Keywords country-of-origin, country image, Fishbein's model, purchase intention

摘要 通过对我国消费者进行问卷调查, 通过实证分析发现, 消费者对国家形象 的感知大体上分为四个构面：与中国关系评价、国家发展程度、整体产品评价、 整体人民评价, 国家形象各构面的组成项目因不同国家而有所差异。将国家形象 作为新的变量引入 Fishbein 模型, 发现模型依然与实际数据吻合, 证明 Fishbein 模型具有较好可扩展性和跨文化适应性。通过对模型进行分析, 发现国家形象间 接地影响消费者的购买意向, 其影响系数因不同产品类别而有所差异, 其中国家 形象对服装产品的购买意向影响最高, 手机产品次之, 对汽车产品的购买意向影 响最低。

关键词 原产国, 国家形象, Fishbein 模型, 购买意向

\section{Introduction}

Under the present economic environment, each country can participate in the process of globalization by leveraging on its own resources, and the entire world has gradually formed a unified market system. A company may seize the development opportunity in making use of and integrating resources globally. However, the company is facing not only domestic competition, but also overseas competition. At the same time, consumers are exposed to an increasing number of brands from foreign companies.

Country-of-origin effect has been one of the most discussed topics in the global marketing literature since 1965 (Al-Sulaiti and Baker, 1998; Han, 1989; Schooler, 1965). There has been research aimed at determining the effect of country image (country-of-origin image, product-country image). Specifically, the effect can be classified into halo effect and summary effect, and influence consumers' belief and the brand attitude (Han, 1989). Some scholars hold that country image can help firms continually maintain competitive advantage in global marketing (Baker and Ballington, 2002; Parameswaran and Pisharodi, 1994). Papadopoulos and Heslop (2000) suggested country image has a significant impact on consumers' purchase decision, and is more important than brand name. Meanwhile, they also believe that all target markets, including consumers, tourists, organization buyers, retail merchants, and overseas investors, are influenced by country or region image. Finally, they propose the concepts of country equity and country branding (Papadopoulos et al., 2000).

Country image is an intangible asset for both government and firm. However, 
no consensus has been reached on how to measure country image. Due to the cultural differences between the East and the West, and because less attention has been given to the country image in China, the cross-culture adaptability of foreign country image scale in domestic research requires further examination. Moreover, the mechanism of the country image and its impact on consumers' purchase intention call for additional research (Tian and Chen, 2004).

China has become the fourth biggest country in terms of total economic output since it implemented reform and open policy in 1978. Consumers in the open Chinese market are exposed to various products and brands of many countries. Therefore, will consumers be influenced by the country image? If they will, how does the country image influence consumers' product evaluation? Is the scale of country image developed by western scholars suitable for China? Given these problems, this study develops a scale of country image which has good reliability and validity, then analyzes how does the country image influence consumers' purchase intention based on Fishbein's theory of reasoned action.

\section{Research background}

\subsection{Country image}

\subsubsection{Definition of country image}

The concept of country image is proposed by western scholars during the study of country-of-origin effects. "The made-in image is the picture, the reputation, the stereotype that businessmen and consumers attach to products of a specific country. This image is created by such variables as representative products, national characteristics, economic and political background, history, and traditions. It has a strong influence on consumer behaviors in the international market, as it is associated with mass communication, personal experience, and views of national opinion leaders." (Nagashima, 1970). Bilkey and Nes (1982) defines country image as consumers' general perceptions of quality for products made in a given country. Roth and Romeo (1992) proposed "country image is the overall perception consumer form of products from a particular country, based on their prior perceptions of the country's production and marketing strengths and weaknesses." Martin and Eroglu (1993) defined country image as the summary of consumers' descriptive belief, inferential belief and informational belief of the country. Country image, in this study, refers to the general perception of a country and the products of the country. 


\subsubsection{Mechanism of country image}

Based on the elaboration likelihood model (ELM) proposed by Petty and Cacioppo (1986), consumers process information by two routes: one is the central route, and the other is the peripheral route. When a consumer has the motivation and the ability of information procession, he will process the information by the central route; when a consumer does not have the motivation and the ability of information procession and there is the peripheral route, he will process the information by the peripheral route. In studies of country-of-origin effects, there are two important findings. First, the information of country-of-origin plays an important role in product appraisal, especially when lack of other product information. Second, the effects of country-of-origin under the condition of multiple cues are not as strong as that of single cue. A possible explanation is that, even if a consumer has the motivation of purchasing products, he/she tends to process information by the peripheral route when he has limited information of products. Country image, as a peripheral cue, possibly affects consumers' purchase intention. The study of Russian tractor sold in the United States conducted by Johansson, Ronkainen and Czinkota (1994) tests the effect of country image as a peripheral cue on product appraisal through country-of-origin evaluation.

According to the cognitive consistency theory, consumers enjoy the balanced psychological status, and if they are psychologically imbalanced, they will feel uneasy or depressed. Heider (1958) holds that if there are imbalances between attitudes, consumers will change the original attitude to keep balance. He first assumes there are ternary relations among "self", "others", and "objects". In the ternary relations, people will try to avoid uneven status and maintain balanced status. Klein, Ettenson and Morris (1998) proposed an animosity model of foreign product purchase based on the study of consumers of Nanjing city in China. They find there is a negative relationship between Chinese consumers' degree of hatred for Japan and purchase intention of Japanese products. The hatred effect is independent of their judgments to Japanese product, and this finding is a good example of cognitive consistency theory.

Fishbein and Ajzen (1975) suggests that belief can be classified into descriptive belief, inferential belief and informational belief. Different kinds of beliefs come from different experiences. The base of descriptive belief is the direct and first-hand experience. The base of informational belief is the indirect and second-hand experience. The inferential belief is beyond the given experience (first-hand and second-hand experience), and it is the consequence of past experience and relevant stimulus. For example, based on his/her experience, a consumer may know the German cars are durable. Because Audi cars are made 
in Germany, the consumer will infer Audi cars are durable. This shows the inferential belief can explain the effects of country image on consumer belief through halo effect. Han (1989) argues that consumer will recode and extract single informational factors to store in his long-term memory and retract when needed. Because of the similar attributes of products from the same country, consumers will extract information from the product of a same country. Country image thus can include many information of the product in that country. Han (1989) proved with evidence that when a consumer is unfamiliar with a country's products, country image will affect his belief and brand attitude through halo effects; when a consumer is familiar with the country's product, country image will directly affect brand attitude through summary effects.

\subsection{Consumer purchase intention}

In consumer purchase intention research, an influential approach to explain antecedents of behavior is Fishbein and Ajzen's theory of reasoned action (Fishbein and Ajzen, 1975). This theory is illustrated in Fig. 1. According to the theory, the premise is that overt behavior is a function of a person's behavioral intention. This construct reflects the individual's motivation to perform the behavior, and individuals with strong intentions are likely to engage in the behavior. The behavioral intention, in turn, depends on his or her attitude toward the behavior and subjective norm. Attitudes are conceptualized as overall positive or negative evaluations of behavior. Subjective norms, is defined as perception of general social pressure from important others to perform or not a given behavior.

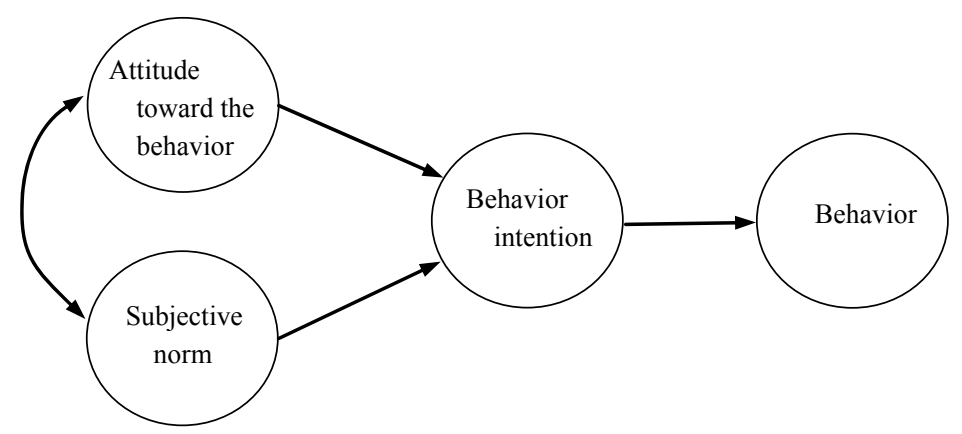

Fig. 1 The model of the theory of reasoned action

Fishbein's behavioral intention model has strong explanatory power in predicting behavior, and can be used in psychology, sociology, marketing and other application areas. However, the model is based on Western Christian culture while the Chinese culture is a typical Confucian culture. The western 
culture emphasizes "individual consciousness", and the Chinese culture focuses on "group consciousness" (Yi, 1995). Some scholars in Hong Kong and South Korea concern about the generalizability of the model (Chan and Lorett, 1998; Lee, 1990). Lee (1990) modified the model by adding "mian $z i$ " (face saving) and group conformity to replace subjective norm. The study finds that face saving and group conformity have significant impact on behavioral intention, and the modified model can be used to interpret South Korean consumers' behavioral intention.

Although no consensus has been reached on how to modify the model to adapt to the Confucian culture background, much research has shown that Fishbein's model has good generalizability in China and South Korea. However, different from Western research, behavioral intention is affected more by subjective norm in collectivism culture (Chan and Lorett, 1998; Lee and Green, 1990). Anyway, Fishbein's behavioral intention model has good cross-culture adaptability and generalizability.

\subsection{Research model}

\subsubsection{Country image and product evaluation}

Consumer product evaluation is primarily based on internal and external cues. Country image is a kind of external cue. Han and Terpstra (1988) found country image has more effects on consumer product evaluation than brand name does. Lee and Copala (1999) found product specific image plays a mediating role between overall country image and consumer evaluation. Regarding to product and brand familiarity, moderate familiarity consumers utilize country-of-origin information less than low or high familiarity consumers. Likewise, regarding to country familiarity, low familiarity consumers rely more on country-of-origin information than high familiarity consumers. Laroche et al. (2005) found country image is a three-dimensional concept consisting of cognitive, affective, and conative components. They also found when a country's image has a strong affective component, its direct influence on product evaluations is stronger than its influence on product beliefs. Alternatively, when a country's image has a strong cognitive component, its direct influence on product evaluations is smaller than its influence on product beliefs. Based on the above studies, we can conclude that country image affects product evaluation obviously.

\subsubsection{Country image and consumer attitude}

Through an empirical test on the halo effect and summary effect, Han (1989) 
indicated that when consumers are not familiar with a country's products, country image may serve as a halo from which consumers form brand belief and then affects their brand attitude. In contrast, as consumers become familiar with a country's products, country image may become a construct that summarizes consumers' beliefs about product attributes and directly affects their attitude toward the brand. We can conclude that whether country image has a direct impact on the attitude depends on circumstances. Erickson, Johansson and Chao (1984) also found variables of country image affect belief about products rather than consumers' attitude. All the above-mentioned research point out that country image has no direct impact on consumers' attitude, but it can indirectly affect consumers' attitude through product evaluation.

\subsubsection{Country image and purchase intention}

When studying how country image affects product evaluation and purchase decision, Chen (2001) found country image has no direct impact on purchase decision, and it has indirect impact on purchase decision through consumers' brand attitude. Chen (2004) also discovered that the country image has no direct impact on purchase intention, but has indirect impact on purchase intention through consumers' trust in product. Yin (2006) found Korean consumers perceive Chinese country image as three constructs: industrialization, production system, and educational level. Through an empirical test, he found industrialization and educational level have significant influence on Korean consumers' Haier (a Chinese company) brand preference, and these three constructs have no significant impact on purchase intention. These studies show country image has no direct impact on purchase intention, and it influences purchase intention indirectly through some mediate variables.

Based on the literature, we propose hypothesis 1:

H1 Country image influences purchase intention indirectly, and it can be added into purchase intention model as a new variable.

\subsubsection{Research model}

Based on these literatures and Fishbein's behavior intention model, we examine how the country image affects purchase intention by adding the variable of the country image into Fishbein's model.

Then, how to incorporate the country image into Fishbein's model? An et al. (2003) surveyed four brands, including LG, Sony, Philip, and Changhong, based on Fishbein's model, to study the effect of country image on Chinese consumers' 
purchase behavior when they buy a single nationality products (the brand origin and the product origin are the same) and when they buy dual nationality products (the brand origin and the product origin are different). The study divides product appraisal into functional appraisal and symbolic appraisal. Functional appraisal only affects brand attitude, without affecting the subjective norm. Symbolic appraisal affects both subjective norm and brand attitude. There are two reasons why this paper is based on An's model. First, An's study is based on Fishbein's model, which is the same as ours. Second, An's study uses four brands of four different countries to study the effect of different country's brand on Chinese consumer purchase intention. An's study uses brand to reflect country image rather than regarding country image as a whole research subject. Therefore, An's study did not point out how country image affects consumer purchase intention. This paper tries to examine the effect of country image on purchase intention based on An's model. Fig.2 is an illustration of this model (Model 1).

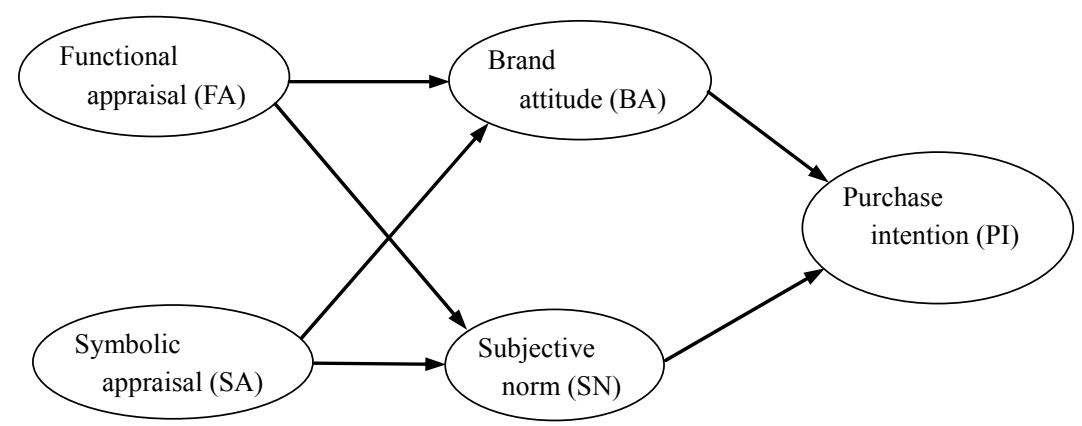

Fig. 2 Model 1

Although the functional appraisal has no impact on subjective norm in An (2003), the study does not do further research after deleting the path between the two. Therefore, we revised model 1 to form the second model (see Fig. 3).

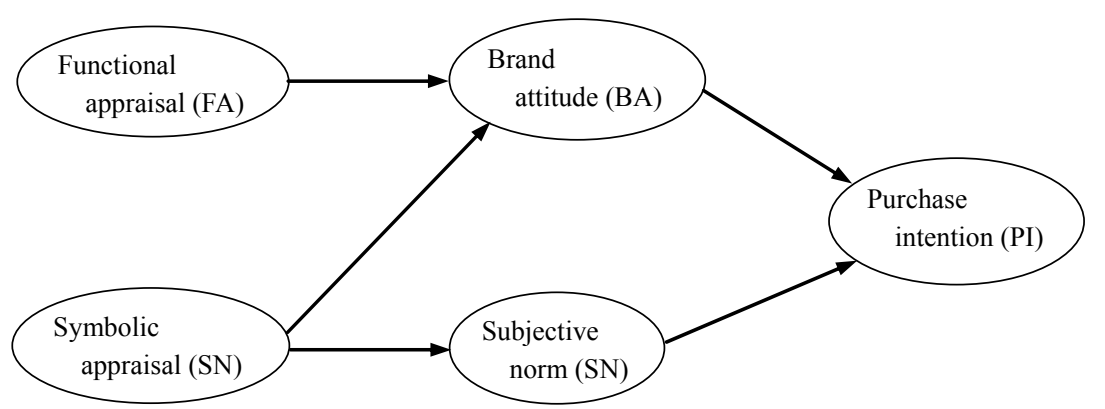

Fig. 3 Model 2 
Finally, based on Fishbein's behavioral intention model, the study adds country image into Model 2, and examines the effects of country image on product appraisal, brand attitude, subjective norm and purchase intention. The relationships between them are presented in Model 3 (see Fig. 4).

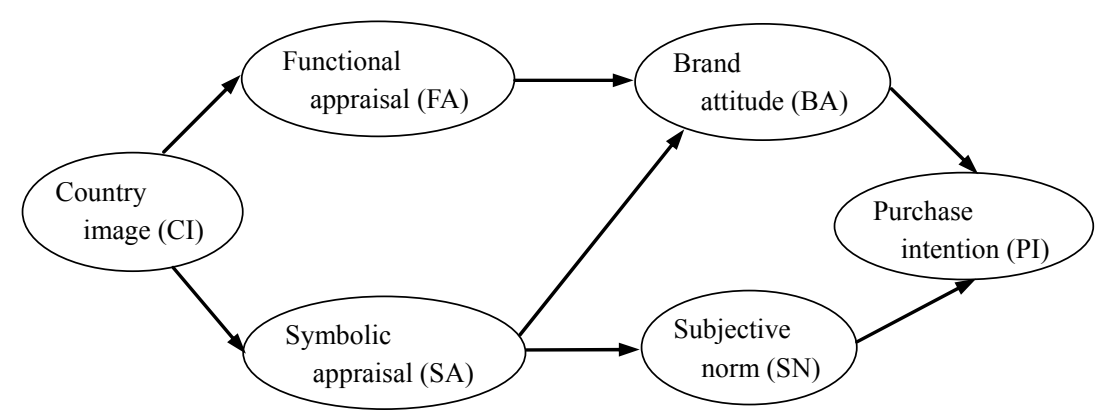

Fig. 4 Model 3

Model 3 introduces country image in, and is based on the modified purchase intention model. Therefore, we proposes hypothesis 2 :

H2 Model 3 is the best model out of all the three models above.

\section{Research design}

\subsection{Measurement of variables}

The study measures six latent variables, and all latent variables are measured by observed variables. The observed variables are measured by five-point Likert Scales.

The scales in the study are drawn from relevant research. Specific measurement items for country image are mainly from the studies of Martin and Eroglu (1993), Parameswaran and Pisharodi (1994), and Laroche et al. (2005). The measurement items consist of items of cognitive image, normative image and emotional image. The items of product functional appraisal are based on the studies of Nagashima (1970, 1977), Krishnakumar (1974) and Chao (1993). The items of product symbolic appraisal are based on the studies of Li et el. (2000) and An et al. (2003). Brand attitude measurement items are designed according to attitude literature. The items of subjective norm are based on the study of Fishbein and Ajzen (1975). The items of purchase intention are from the study of Ajzen and Fishbein (1980) (see measurement items in the appendix). 


\subsection{Sampling and data collection}

The focal countries of this study are the USA, Germany, Japan and South Korea. The reasons for choosing these countries are that they are major trading partners of China, and their goods are sold widely in the Chinese market. Moreover, Chinese consumers are familiar with these countries and brands of these countries.

The product categories in the study are car, cell phone, and athletic apparel. According to FCB matrix, the involvement of car is the highest, the second highest is cell phone, and the lowest is athletic apparel. Brands of car included in this study are GE, Volkswagen, Toyota, and Hyundai. Brands of cell phone are Motorola, Siemens, Sony, and Samsung. Brands of athletic apparel are Nike, Adidas, Mizuno and Rapido.

The survey covered residents who live in Shanghai, Beijing, Wuhan, Qingdao and Shenyang city. 1700 questionnaires were issued, in which 1677 were returned, including 1257 valid ones (response rate $=73.9 \%$ ).

\section{Analysis}

\subsection{Reliability and validity analysis}

Reliability is an assessment of the degree of consistency between multiple measurements of a variable. Cronbach's Alpha coefficient is used to assess the consistency of the entire scale, and when the item-total correlation coefficient decreases to 0.4 or below, the item will be deleted. Analysis result shows that reliability coefficients of country image construct are between 0.754 and 0.909 , which satisfies the needs of further research.

Validity is the extent to which a scale or a set of measures accurately represent the concept of interest. The scale validity consists of content validity and construct validity. The scale of country image in this paper is based on prior research, and its content validity has been proved in prior research.

In this paper, country image is classified into three constructs. However, country image can be the consequences of country-of-origin, that is, country image dimensions may vary in different countries. This paper studies country image dimensions of four different countries (USA, Germany, Japan and South Korea) through exploratory factor analysis. The criteria to screen the factors to retain is factors' Eigenvalues should be greater than 1.0 and factor loadings be greater than 0.6 . The screening process is repeated for several times to ensure its validity. Moreover, the country image scale includes 32 items, which is a great inconvenience in the following analysis. Thus, this paper conducts factor analysis for each of the 
four countries to reduce the number of variables, and use factor scores to replace origin values as observable variables in structural equation modeling (see Table 1).

Table 1 Results of factor analysis of country image

\begin{tabular}{|c|c|c|c|}
\hline Country & KMO Sig. & $\begin{array}{l}\text { Proportion of } \\
\text { variance } \\
\text { accounted } \\
\text { for }(\%)\end{array}$ & Factors of country image \\
\hline USA & 0.7840 .000 & 62.296 & $\begin{array}{l}\text { Degree of country development, general people } \\
\text { appraisal, appraisal of product in general, } \\
\text { appraisal of China-USA relationship }\end{array}$ \\
\hline Germany & 0.9000 .000 & 66.349 & $\begin{array}{l}\text { Degree of country development, general product } \\
\text { appraisal, general people appraisal, interactive } \\
\text { intention, cultural similarity appraisal }\end{array}$ \\
\hline Japan & 0.9090 .000 & 65.836 & $\begin{array}{l}\text { General product appraisal, degree of country } \\
\text { development, general people appraisal, appraisal } \\
\text { of China-Japan relationship }\end{array}$ \\
\hline South Korea & 0.8970 .000 & 63.384 & $\begin{array}{l}\text { Appraisal of China-South Korea relationship, degree } \\
\text { of country development, appraisal of product in } \\
\text { general, appraisal of people in general }\end{array}$ \\
\hline
\end{tabular}

The KMO values in Table 1 show that KMO value of USA is close to 0.8 , KMO values of Germany, Japan, and Korea are greater than 0.8. In addition, a statistically significant Bartlett's test (significant at level 0.001) indicates that the screened questionnaire is suitable for factor analysis. The extracted factors from the orthogonal rotation show there are four factors of country image in USA, Japan and South Korea, including degree of country development, general product appraisal, appraisal of relationship with China, and general people appraisal. The factors of German country image include degree of country development, general product appraisal, general people appraisal, interactive intention and cultural similarity appraisal. These findings are different from previous studies. Parameswaran and Pisharodi (1994) found dimensions of country image are stable, but items of these dimensions may be dependent variables of country-in-origin, that is, items of country image dimensions vary from country to country. This paper finds that not all dimensions of country image in different countries are the same, which indicate consumer perceptions of country image are complicated in nature.

The results of exploratory factor analysis are used to appraise the construct validity of country image scale. The construct validity is assessed in terms of convergent validity and discriminant validity. Factor analysis results are summarized in Table 2 to Table 6 .

According to Fornell and Larker (1981), we can assess convergent validity according to 3 criteria: All the standardized factor loadings exceed the minimum 
values of 0.5 and all factors loadings of the final measures are highly significant $(p<0.05)$; The average construct reliability estimates are all above the recommended value of 0.8 ; Average variance extracted (AVE) are over 0.5.

Table 2 Results of confirmatory factor analysis of country image

\begin{tabular}{|c|c|c|c|c|c|c|c|c|c|c|c|}
\hline \multirow[b]{2}{*}{ Dimensions } & \multicolumn{2}{|c|}{ USA } & \multirow[b]{2}{*}{ Dimensions } & \multicolumn{2}{|c|}{ Germany } & \multirow[b]{2}{*}{ Dimensions } & \multicolumn{2}{|r|}{ Japan } & \multirow[b]{2}{*}{ Dimensions } & \multicolumn{2}{|c|}{ South Korea } \\
\hline & Code & $\begin{array}{l}\text { Factor } \\
\text { loadings }\end{array}$ & & Code ${ }^{\mathrm{F}}$ & $\begin{array}{l}\text { Factor } \\
\text { loadings }\end{array}$ & & Code & $\begin{array}{l}\text { Factor } \\
\text { loadings }\end{array}$ & & Code & $\begin{array}{l}\text { Factor } \\
\text { loadings }\end{array}$ \\
\hline \multirow{4}{*}{$\begin{array}{l}\text { Degree of } \\
\text { country } \\
\text { development }\end{array}$} & A11 & $\begin{array}{c}0.81 \\
(15.42)\end{array}$ & \multirow{6}{*}{$\begin{array}{l}\text { Degree of } \\
\text { country } \\
\text { development }\end{array}$} & A11 & $\begin{array}{c}0.74 \\
(16.13)\end{array}$ & \multirow{7}{*}{$\begin{array}{l}\text { General } \\
\text { product } \\
\text { appraisal }\end{array}$} & A31 & $\begin{array}{c}0.81 \\
(14.03)\end{array}$ & \multirow{9}{*}{$\begin{array}{c}\text { China-Korea } \\
\text { relationship } \\
\text { appraisal }\end{array}$} & A110 & $\begin{array}{c}0.79 \\
(13.40)\end{array}$ \\
\hline & A12 & $\begin{array}{c}0.50 \\
(12.47)\end{array}$ & & A12 & $\begin{array}{c}0.72 \\
(18.56)\end{array}$ & & A32 & $\begin{array}{c}0.74 \\
(13.92)\end{array}$ & & A111 & $\begin{array}{c}0.80 \\
(14.49)\end{array}$ \\
\hline & $\mathrm{A} 13$ & $\begin{array}{c}0.75 \\
(16.07)\end{array}$ & & A13 & $\begin{array}{c}0.79 \\
(18.38)\end{array}$ & & A33 & $\begin{array}{c}0.81 \\
(16.98)\end{array}$ & & A112 & $\begin{array}{c}0.70 \\
(12.19)\end{array}$ \\
\hline & A15 & $\begin{array}{c}0.78 \\
(15.03)\end{array}$ & & $\mathrm{A} 14$ & $\begin{array}{c}0.74 \\
(16.31)\end{array}$ & & A34 & $\begin{array}{c}0.85 \\
(15.58)\end{array}$ & & A113 & $\begin{array}{c}0.83 \\
(14.82)\end{array}$ \\
\hline \multirow{4}{*}{$\begin{array}{l}\text { General } \\
\text { people } \\
\text { appraisal }\end{array}$} & A25 & $\begin{array}{c}0.71 \\
(13.14)\end{array}$ & & A15 & $\begin{array}{c}0.78 \\
(18.22)\end{array}$ & & A35 & $\begin{array}{c}0.88 \\
(17.44)\end{array}$ & & A114 & $\begin{array}{c}0.78 \\
(13.21)\end{array}$ \\
\hline & A26 & $\begin{array}{c}0.75 \\
(14.89)\end{array}$ & & A16 & $\begin{array}{c}0.72 \\
(13.39)\end{array}$ & & A36 & $\begin{array}{c}0.62 \\
(11.98)\end{array}$ & & $\mathrm{A} 21$ & $\begin{array}{c}0.72 \\
(13.62)\end{array}$ \\
\hline & A27 & $\begin{array}{c}0.65 \\
(13.48)\end{array}$ & \multirow{7}{*}{$\begin{array}{l}\text { General } \\
\text { product } \\
\text { appraisal }\end{array}$} & A 31 & $\begin{array}{c}0.69 \\
(14.59)\end{array}$ & & A 37 & $\begin{array}{c}0.72 \\
(12.18)\end{array}$ & & A25 & $\begin{array}{c}0.74 \\
(14.62)\end{array}$ \\
\hline & A28 & $\begin{array}{c}0.58 \\
(11.07) \\
\end{array}$ & & A32 & $\begin{array}{c}0.58 \\
(12.72)\end{array}$ & \multirow{6}{*}{$\begin{array}{l}\text { Degree of } \\
\text { country } \\
\text { developmen }\end{array}$} & A11 & $\begin{array}{c}0.91 \\
(15.96)\end{array}$ & & A26 & $\begin{array}{c}0.75 \\
(14.38)\end{array}$ \\
\hline \multirow{4}{*}{$\begin{array}{l}\text { General } \\
\text { product } \\
\text { appraisal }\end{array}$} & A31 & $\begin{array}{c}0.61 \\
(10.77)\end{array}$ & & A33 & $\begin{array}{c}0.68 \\
(16.57)\end{array}$ & & A12 & $\begin{array}{c}0.82 \\
(17.90)\end{array}$ & & A27 & $\begin{array}{c}0.73 \\
(11.92) \\
\end{array}$ \\
\hline & A 32 & $\begin{array}{c}0.58 \\
(10.78)\end{array}$ & & A34 & $\begin{array}{c}0.69 \\
(14.49)\end{array}$ & & A13 & $\begin{array}{c}0.94 \\
(16.54)\end{array}$ & \multirow{5}{*}{$\begin{array}{l}\text { Degree of } \\
\text { country } \\
\text { development }\end{array}$} & A11 & $\begin{array}{c}0.90 \\
(16.99)\end{array}$ \\
\hline & A33 & $\begin{array}{c}0.68 \\
(13.51)\end{array}$ & & A35 & $\begin{array}{c}0.64 \\
(14.31)\end{array}$ & & $\mathrm{A} 14$ & $\begin{array}{c}0.87 \\
(17.13)\end{array}$ & & A12 & $\begin{array}{c}0.89 \\
(16.42)\end{array}$ \\
\hline & A34 & $\begin{array}{c}0.54 \\
(10.01)\end{array}$ & & A36 & $\begin{array}{c}0.65 \\
(14.44)\end{array}$ & & A15 & $\begin{array}{c}0.87 \\
(16.02)\end{array}$ & & A13 & $\begin{array}{c}0.91 \\
(17.27)\end{array}$ \\
\hline \multirow{7}{*}{$\begin{array}{c}\text { China-USA } \\
\text { relationship } \\
\text { appraisal }\end{array}$} & A111 & $\begin{array}{c}0.78 \\
(11.48)\end{array}$ & & A37 & $\begin{array}{c}0.65 \\
(14.07)\end{array}$ & & A16 & $\begin{array}{c}0.75 \\
(11.48)\end{array}$ & & A14 & $\begin{array}{c}0.71 \\
(12.39)\end{array}$ \\
\hline & A112 & $\begin{array}{c}0.72 \\
(12.51)\end{array}$ & & A25 & $\begin{array}{c}0.75 \\
(15.23)\end{array}$ & \multirow{6}{*}{$\begin{array}{l}\text { General } \\
\text { people } \\
\text { appraisal }\end{array}$} & $\mathrm{A} 21$ & $\begin{array}{c}0.83 \\
(12.71)\end{array}$ & & A15 & $\begin{array}{c}0.78 \\
(15.04) \\
\end{array}$ \\
\hline & A113 & $\begin{array}{c}0.72 \\
(11.48)\end{array}$ & $\begin{array}{l}\text { General } \\
\text { people }\end{array}$ & A26 & $\begin{array}{c}0.80 \\
(17.60)\end{array}$ & & A 25 & $\begin{array}{c}0.95 \\
(14.83)\end{array}$ & \multirow{5}{*}{$\begin{array}{l}\text { General } \\
\text { product } \\
\text { appraisal }\end{array}$} & A31 & $\begin{array}{c}0.73 \\
(13.60)\end{array}$ \\
\hline & & & & A27 & $\begin{array}{c}0.75 \\
(16.42) \\
\end{array}$ & & A26 & $\begin{array}{c}0.96 \\
(17.52)\end{array}$ & & A 32 & $\begin{array}{c}0.64 \\
(12.53)\end{array}$ \\
\hline & & & \multirow{3}{*}{$\begin{array}{c}\text { Interactive } \\
\text { intention }\end{array}$} & A29 & $\begin{array}{c}0.64 \\
(12.11)\end{array}$ & & A27 & $\begin{array}{c}0.98 \\
(18.86)\end{array}$ & & A33 & $\begin{array}{c}0.76 \\
(16.07)\end{array}$ \\
\hline & & & & $\mathrm{A} 210$ & $\begin{array}{c}0.72 \\
(12.96)\end{array}$ & & A28 & $\begin{array}{c}1.03 \\
(16.48)\end{array}$ & & A34 & $\begin{array}{c}0.70 \\
(13.57)\end{array}$ \\
\hline & & & & A211 & $\begin{array}{c}0.83 \\
(13.50)\end{array}$ & & A29 & $\begin{array}{c}0.85 \\
(13.84)\end{array}$ & & A35 & $\begin{array}{c}0.63 \\
(12.17)\end{array}$ \\
\hline
\end{tabular}




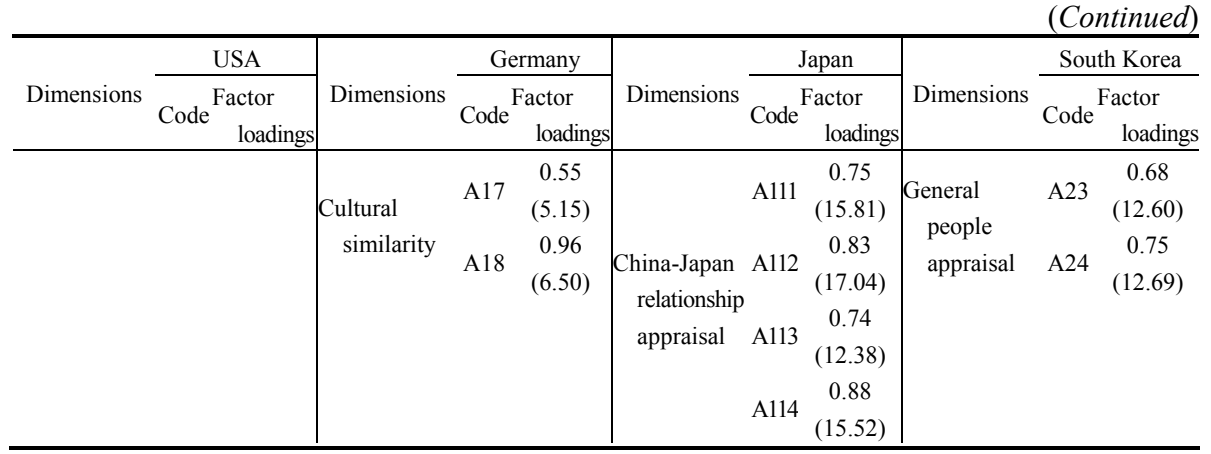

Note: Brackets for $T$ values.

Table 3 Correlation coefficients, standard errors, average variances extracted and construct reliability of dimensions of USA country image

\begin{tabular}{|c|c|c|c|c|c|}
\hline & $\begin{array}{l}\text { Degree of } \\
\text { country } \\
\text { development }\end{array}$ & $\begin{array}{l}\text { General people } \\
\text { appraisal }\end{array}$ & $\begin{array}{l}\text { General } \\
\text { product } \\
\text { appraisal }\end{array}$ & $\begin{array}{l}\text { China-USA } \\
\text { relationship } \\
\text { appraisal }\end{array}$ & $\begin{array}{l}\text { Construct } \\
\text { reliability }\end{array}$ \\
\hline $\begin{array}{l}\text { Degree of } \\
\text { country } \\
\text { development }\end{array}$ & 0.915895 & & & & 0.976895 \\
\hline $\begin{array}{l}\text { General people } \\
\text { appraisal }\end{array}$ & $\begin{array}{c}0.25485 \\
(0.06419)\end{array}$ & 0.898802 & & & 0.972382 \\
\hline $\begin{array}{l}\text { General product } \\
\text { appraisal }\end{array}$ & $\begin{array}{c}0.43313 \\
(0.05986)\end{array}$ & $\begin{array}{c}0.35099 \\
(0.06503)\end{array}$ & 0.871868 & & 0.964309 \\
\hline $\begin{array}{l}\text { China-USA } \\
\text { relationship } \\
\text { appraisal }\end{array}$ & $\begin{array}{c}0.12485 \\
(0.07014)\end{array}$ & $\begin{array}{c}0.52507 \\
(0.05822)\end{array}$ & $\begin{array}{c}0.25922 \\
(0.07150)\end{array}$ & 0.897335 & 0.963224 \\
\hline
\end{tabular}

Note: Brackets for standard errors; average variances extracted are on the diagonal of the table.

Table 4 Correlation coefficients, standard errors, average variances extracted, construct reliability of dimensions of German country image

\begin{tabular}{|c|c|c|c|c|c|c|}
\hline & $\begin{array}{l}\text { Degree of } \\
\text { country } \\
\text { development }\end{array}$ & $\begin{array}{l}\text { General } \\
\text { product } \\
\text { t } \quad \text { appraisal } \\
\end{array}$ & $\begin{array}{l}\text { General } \\
\text { people } \\
\text { appraisal } \\
\end{array}$ & $\begin{array}{l}\text { Interactive } \\
\text { intention }\end{array}$ & $\begin{array}{l}\text { Cultural } \\
\text { similarity } \\
\text { appraisal } \\
\end{array}$ & $\begin{array}{l}\text { Construct } \\
\text { reliability } \\
\end{array}$ \\
\hline $\begin{array}{c}\text { Degree of country } \\
\text { development }\end{array}$ & 0.925742 & & & & & 0.98679 \\
\hline $\begin{array}{l}\text { General product } \\
\text { appraisal }\end{array}$ & $\begin{array}{c}0.52182 \\
(0.04682)\end{array}$ & 0.904799 & & & & 0.98271 \\
\hline $\begin{array}{l}\text { General people } \\
\text { appraisal }\end{array}$ & $\begin{array}{c}0.53622 \\
(0.04739)\end{array}$ & $\begin{array}{c}0.62398 \\
(0.04300)\end{array}$ & 0.926446 & & & 0.97419 \\
\hline $\begin{array}{l}\text { Interactive } \\
\text { intention }\end{array}$ & $\begin{array}{c}0.37020 \\
(0.05979)\end{array}$ & $\begin{array}{c}0.52367 \\
(0.05366)\end{array}$ & $\begin{array}{c}0.62158 \\
(0.04939)\end{array}$ & 0.905052 & & 0.96585 \\
\hline $\begin{array}{l}\text { Cultural similarity } \\
\text { appraisal }\end{array}$ & $\begin{array}{c}0.18125 \\
(0.06941)\end{array}$ & $\begin{array}{c}0.24934 \\
(0.07230)\end{array}$ & $\begin{array}{c}0.32772 \\
(0.07626)\end{array}$ & $\begin{array}{c}0.45483 \\
(0.08545)\end{array}$ & 0.827182 & 0.89445 \\
\hline
\end{tabular}

Note: Brackets for standard errors; average variances extracted are on the diagonal of the table. 
Table 5 Correlation coefficients, standard errors, average variances extracted, construct reliability of dimensions of Japanese country image

\begin{tabular}{|c|c|c|c|c|c|}
\hline & $\begin{array}{l}\text { General } \\
\text { product } \\
\text { appraisal }\end{array}$ & $\begin{array}{l}\text { Degree of } \\
\text { country } \\
\text { development }\end{array}$ & $\begin{array}{l}\text { General } \\
\text { people } \\
\text { appraisal }\end{array}$ & $\begin{array}{l}\text { China-Japan } \\
\text { relationship } \\
\text { appraisal }\end{array}$ & $\begin{array}{l}\text { Construct } \\
\text { reliability }\end{array}$ \\
\hline $\begin{array}{l}\text { General product } \\
\text { appraisal }\end{array}$ & 0.91932 & & & & 0.987476 \\
\hline $\begin{array}{c}\text { Degree of country } \\
\text { development }\end{array}$ & $\begin{array}{c}0.61882 \\
(0.04140)\end{array}$ & 0.930974 & & & 0.987735 \\
\hline $\begin{array}{l}\text { General people } \\
\text { appraisal }\end{array}$ & $\begin{array}{c}0.41910 \\
(0.05315)\end{array}$ & $\begin{array}{c}0.36820 \\
(0.05514)\end{array}$ & 0.935943 & & 0.988659 \\
\hline $\begin{array}{l}\text { China-Japan relationship } \\
\text { appraisal }\end{array}$ & $\begin{array}{c}0.22868 \\
(0.06185)\end{array}$ & $\begin{array}{c}0.13683 \\
(0.06347)\end{array}$ & $\begin{array}{c}0.63374 \\
(0.04182)\end{array}$ & 0.923641 & 0.979639 \\
\hline
\end{tabular}

Note: Brackets for standard errors; average variances extracted are on the diagonal of the table.

Table 6 Correlation coefficients, standard errors, average variances extracted, construct reliability of dimensions of Korean country image

\begin{tabular}{|c|c|c|c|c|c|}
\hline & $\begin{array}{l}\text { China-South } \\
\text { Korea } \\
\text { relationship } \\
\text { appraisal }\end{array}$ & $\begin{array}{l}\text { Degree of } \\
\text { country } \\
\text { development }\end{array}$ & $\begin{array}{l}\text { General } \\
\text { product } \\
\text { appraisal }\end{array}$ & $\begin{array}{l}\text { General people } \\
\text { appraisal }\end{array}$ & $\begin{array}{l}\text { Construct } \\
\text { reliability }\end{array}$ \\
\hline $\begin{array}{l}\text { China-Korea } \\
\text { relationship } \\
\text { appraisal }\end{array}$ & 0.911999 & & & & 0.989363 \\
\hline $\begin{array}{l}\text { Degree of country } \\
\text { development }\end{array}$ & $\begin{array}{c}0.43921 \\
(0.05399)\end{array}$ & 0.929389 & & & 0.984897 \\
\hline $\begin{array}{l}\text { General product } \\
\text { appraisal }\end{array}$ & $\begin{array}{c}0.44334 \\
(0.05542)\end{array}$ & $\begin{array}{c}0.52503 \\
\left(\begin{array}{lll}0.051 & 03\end{array}\right)\end{array}$ & 0.90414 & & 0.97913 \\
\hline $\begin{array}{l}\text { General people } \\
\text { appraisal }\end{array}$ & $\begin{array}{c}0.61938 \\
(0.05087)\end{array}$ & $\begin{array}{c}0.46290 \\
(0.06029)\end{array}$ & $\begin{array}{c}0.47603 \\
(0.06145)\end{array}$ & 0.90032 & 0.947426 \\
\hline
\end{tabular}

Note: Brackets for standard errors; average variances extracted are on the diagonal of the table.

In Table 2, we find factor loadings of all measurement items exceed 0.5 and are highly significant $(p<0.05)$. In Table 3 to Table 6 , we find construct reliability of all dimensions are above 0.8 , and average variance extracted are over 0.8 , greater than the recommended value of 0.5 . Thus, we can conclude that the scale of the country image in this study has good convergent validity. Moreover, results indicate that factors have highly correlated with each other, and none of the correlation coefficients plus the corresponding standard errors exceed the value of 1 , which show the study has good discriminant validity.

The paper clarifies briefly about the purchase intention model in the following, because reliability and validity analysis methods of variables in purchase intention model are similar as the analysis method of the country image.

The purchase intention model in the study of An et al. (2003) consists of five 
dimensions, namely product functional appraisal, product symbolic appraisal, brand attitude, subjective norm and purchase intention. The measurement scale of subjective norm has only one item. Before analyzing the data, the paper examined the reliability of other four dimensions. The results of reliability analysis show that correlation coefficients of the sum of all items are above the recommend value of 0.4 , and reliability coefficients of all the dimensions are between $0.602-0.902$. Therefore, the scales in this study have good reliability, and could be used for data analysis.

The measurement items of variables of purchase intention in this paper are carefully revised based on previous research. It is believed that they have good content validity. Moreover, the results of confirmatory factor analysis show that all the factor loadings exceed 0.5 and are highly significant $(p<0.05, T$ value $>$ 1.96). Construct reliabilities of purchase intentions are above 0.9, greater than the recommended value of 0.8 . Average variances extracted are all over 0.85 , greater than the recommended value of 0.5 . Therefore, the scale of purchase intention has good convergent validity. Results of discriminant validity check indicate that factors have high correlation with each other, and none of the correlation coefficients plus the corresponding standard errors exceed the value of 1 , showing the scale of purchase intention has good discriminant validity.

\subsection{Structural equation modeling analysis}

\subsubsection{Fit indices}

To test the fitness between the theoretical model and sample data, it is necessary to compare the estimated covariance matrix (E) and the observed sample covariance matrix (S). The overall difference between two matrices can be denoted by fit indices. Fit indices can be classified into absolute index and relative index. According to Hou et al. (2004), this study uses a combination of absolute index and relative index as criteria (see Table 7).

Table 7 Criteria of model fit indices

\begin{tabular}{llllllll}
\hline Fit indices & $\chi^{2} /$ d.f. & RMSEA & SRMR & GFI & NFI & NNFI & CFI \\
\hline \multirow{2}{*}{ Criteria } & $(2,5)$ & $<0.1$, acceptable model fit & & & & & \\
& & $<0.05$, good model fit \\
& $<0.01$, best suited model fit & & $<0.08$ & $>0.9$ & $>0.9$ & $>0.9$ & $>0.9$ \\
& & & & & \\
\hline
\end{tabular}

In Table 7, the first four fit indices are absolute indices that are sensitive to size of the sample. Under certain different circumstances, there may be bias using these indices ( $\mathrm{Hu}$ and Bentle, 1998). Other there indices are relative fit indices which are not influenced by sample size. 


\subsubsection{Model fit indices}

LISREL 8.7 is used to analyze covariance matrix and determine the fitness of the models. The fit indices of the three models are in Table 8 .

Table 8 Models fit indices

\begin{tabular}{|c|c|c|c|c|c|c|c|c|c|c|}
\hline Country & Product & Model & $\chi^{2}$ & $\chi^{2 / d . f .}$ & RMSEA & SRMR & GFI & NFI & NNFI & CFI \\
\hline \multirow{9}{*}{ USA } & \multirow[t]{3}{*}{$\mathrm{GE}$} & 1 & 338.80 & 2.65 & 0.072 & 0.053 & 0.89 & 0.95 & 0.96 & 0.97 \\
\hline & & 2 & 345.4 & 2.68 & 0.073 & 0.054 & 0.89 & 0.95 & 0.96 & 0.97 \\
\hline & & 3 & 419.57 & 2.08 & 0.058 & 0.052 & 0.89 & 0.94 & 0.96 & 0.97 \\
\hline & \multirow[t]{3}{*}{ Motorola } & 1 & 287.24 & 2.24 & 0.064 & 0.057 & 0.90 & 0.96 & 0.97 & 0.98 \\
\hline & & 2 & 327.18 & 2.54 & 0.071 & 0.072 & 0.89 & 0.95 & 0.97 & 0.97 \\
\hline & & 3 & 441.27 & 2.18 & 0.063 & 0.067 & 0.88 & 0.94 & 0.96 & 0.97 \\
\hline & \multirow[t]{3}{*}{ Nike } & 1 & 330.79 & 2.58 & 0.071 & 0.053 & 0.90 & 0.96 & 0.97 & 0.97 \\
\hline & & 2 & 366.46 & 2.84 & 0.076 & 0.067 & 0.89 & 0.95 & 0.96 & 0.97 \\
\hline & & 3 & 464.36 & 2.30 & 0.064 & 0.066 & 0.88 & 0.94 & 0.96 & 0.96 \\
\hline \multirow{9}{*}{ Germeny } & \multirow[t]{3}{*}{ Volkswagen } & 1 & 361.71 & 2.83 & 0.078 & 0.063 & 0.88 & 0.94 & 0.96 & 0.96 \\
\hline & & 2 & 409.26 & 3.17 & 0.085 & 0.073 & 0.87 & 0.94 & 0.95 & 0.96 \\
\hline & & 3 & 551.42 & 2.47 & 0.070 & 0.068 & 0.86 & 0.92 & 0.95 & 0.95 \\
\hline & \multirow[t]{3}{*}{ Siemens } & 1 & 297.19 & 2.32 & 0.065 & 0.050 & 0.90 & 0.97 & 0.97 & 0.98 \\
\hline & & 2 & 326.64 & 2.53 & 0.070 & 0.056 & 0.90 & 0.97 & 0.97 & 0.98 \\
\hline & & 3 & 443.75 & 2.00 & 0.056 & 0.057 & 0.89 & 0.96 & 0.97 & 0.98 \\
\hline & \multirow[t]{3}{*}{ Adidas } & 1 & 385.41 & 3.01 & 0.080 & 0.052 & 0.88 & 0.95 & 0.96 & 0.97 \\
\hline & & 2 & 430.91 & 3.34 & 0.086 & 0.066 & 0.87 & 0.95 & 0.95 & 0.96 \\
\hline & & 3 & 544.08 & 2.44 & 0.067 & 0.061 & 0.87 & 0.94 & 0.96 & 0.96 \\
\hline \multirow{9}{*}{ Japan } & \multirow[t]{3}{*}{ Toyota } & 1 & 347.69 & 2.72 & 0.075 & 0.054 & 0.87 & 0.96 & 0.97 & 0.98 \\
\hline & & 2 & 363.92 & 2.82 & 0.078 & 0.056 & 0.88 & 0.96 & 0.97 & 0.98 \\
\hline & & 3 & 494.51 & 2.45 & 0.069 & 0.063 & 0.87 & 0.95 & 0.97 & 0.97 \\
\hline & \multirow[t]{3}{*}{ Sony } & 1 & 374.45 & 2.93 & 0.080 & 0.055 & 0.88 & 0.96 & 0.97 & 0.97 \\
\hline & & 2 & 401.68 & 3.11 & 0.084 & 0.064 & 0.87 & 0.96 & 0.97 & 0.97 \\
\hline & & 3 & 526.93 & 2.61 & 0.073 & 0.065 & 0.86 & 0.95 & 0.96 & 0.97 \\
\hline & \multirow[t]{3}{*}{ Mizuno } & 1 & 302.43 & 2.36 & 0.067 & 0.043 & 0.90 & 0.97 & 0.98 & 0.98 \\
\hline & & 2 & 322.03 & 2.50 & 0.070 & 0.055 & 0.89 & 0.96 & 0.97 & 0.98 \\
\hline & & 3 & 440.27 & 2.18 & 0.062 & 0.054 & 0.88 & 0.96 & 0.97 & 0.97 \\
\hline \multirow{9}{*}{ South Korea } & \multirow[t]{3}{*}{ Hyundai } & 1 & 331.17 & 2.59 & 0.075 & 0.057 & 0.89 & 0.95 & 0.96 & 0.97 \\
\hline & & 2 & 349.27 & 2.71 & 0.077 & 0.061 & 0.88 & 0.95 & 0.96 & 0.97 \\
\hline & & 3 & 470.38 & 2.33 & 0.068 & 0.060 & 0.87 & 0.93 & 0.96 & 0.96 \\
\hline & \multirow{3}{*}{ Samsung } & 1 & 324.26 & 2.53 & 0.073 & 0.049 & 0.89 & 0.96 & 0.97 & 0.98 \\
\hline & & 2 & 359.21 & 2.78 & 0.079 & 0.059 & 0.88 & 0.96 & 0.97 & 0.98 \\
\hline & & 3 & 442.78 & 2.19 & 0.065 & 0.059 & 0.88 & 0.96 & 0.97 & 0.98 \\
\hline & \multirow[t]{3}{*}{ Rapido } & 1 & 328.98 & 2.57 & 0.074 & 0.050 & 0.89 & 0.96 & 0.97 & 0.98 \\
\hline & & 2 & 343.52 & 2.66 & 0.076 & 0.051 & 0.88 & 0.96 & 0.97 & 0.97 \\
\hline & & 3 & 429.20 & 2.15 & 0.063 & 0.050 & 0.88 & 0.95 & 0.97 & 0.97 \\
\hline
\end{tabular}

Although $p=0.000$ in all the theoretical models, as the indices are vulnerable to the sample size. we combine the absolute indices and the relative indices to make 
judgments. In table 8 , the values of $\chi^{2} / d . f$. are between 2.00 and 3.17 , which are acceptable; the values of RMSEA are between 0.056 and 0.086 , less than the recommended value of 0.1 ; the values of SRMR are between 0.043 and 0.073 , less than 0.08 ; the values of GFI are between 0.86 and 0.90 , close to 0.90 . At the same time, the values of NFI, NNFI, and CFI are much greater than 0.9. Therefore, the three models are all acceptable.

In order to compare fitness of the models, this paper conducts Friedman non-parametric paired test to $\chi^{2} / d . f$., RMSEA, SRMR, GFI of the models (see Table 9).

Table 9 Friedman non-parametric paired test: Average rank

\begin{tabular}{lcccc}
\hline \multicolumn{1}{c}{ Fitness index } & Model 1 & Model 2 & Model 3 & Sig. \\
\hline \multicolumn{1}{c}{$\chi^{2} /$ d.f. } & 2.00 & 3.00 & 1.00 & 0.000 \\
RMSEA & 2.00 & 3.00 & 1.00 & 0.000 \\
SRMR & 1.13 & 2.71 & 2.17 & 0.000 \\
GFI & 2.75 & 2.00 & 1.25 & 0.000 \\
\hline
\end{tabular}

The results of Table 9 show that there are obvious differences among these models in terms of fix indices. The fitness of Model 3 is better than that of Model 1 and Model 2. H2 is supported.

\subsubsection{Path coefficient}

This paper uses completely standardized solutions to estimate the regression parameters of the three models (see Table 10-Table 12).

Table 10 Path coefficients of model 1

\begin{tabular}{llcccccc}
\hline & & $\mathrm{FA} \rightarrow \mathrm{BA}$ & $\mathrm{SA} \rightarrow \mathrm{BA}$ & $\mathrm{FA} \rightarrow \mathrm{SN}$ & $\mathrm{SA} \rightarrow \mathrm{SN}$ & $\mathrm{BA} \rightarrow \mathrm{PI}$ & $\mathrm{SN} \rightarrow \mathrm{PI}$ \\
\hline USA & GE & 0.39 & 0.53 & 0.27 & 0.56 & $0.17^{*}$ & $0.63^{*}$ \\
& & $(4.62)$ & $(6.18)$ & $(2.94)$ & $(6.08)$ & $(1.18)$ & $(3.33)$ \\
& \multirow{4}{*}{ Motorola } & 0.65 & 0.31 & 0.40 & 0.19 & 0.57 & $0.33^{*}$ \\
& & $(8.83)$ & $(4.65)$ & $(6.38)$ & $(3.06)$ & $(3.10)$ & $(1.01)$ \\
& \multirow{4}{*}{ Nike } & 0.79 & $0.14^{*}$ & 0.52 & $0.05^{*}$ & 0.57 & $0.32^{*}$ \\
& & $(9.17)$ & $(1.81)$ & $(6.96)$ & $(0.71)$ & $(2.28)$ & $(0.76)$ \\
\hline \multirow{6}{*}{ Germany } & Volkswagen & 0.65 & 0.32 & $0.11^{*}$ & $0.01^{*}$ & 0.61 & 0.05 \\
& & $(10.93)$ & $(5.67)$ & $(1.34)$ & $(0.16)$ & $(6.74)$ & $(2.76)$ \\
& \multirow{4}{*}{ Siemens } & 0.56 & 0.42 & $0.14^{*}$ & $0.06^{*}$ & 0.76 & 0.07 \\
& & $(10.69)$ & $(8.18)$ & $(1.94)$ & $(0.83)$ & $(8.99)$ & $(9.01)$ \\
& \multirow{4}{*}{ Adidas } & 0.73 & 0.28 & 0.42 & $0.11^{*}$ & $0.71^{*}$ & $0.22^{*}$ \\
& & $(12.35)$ & $(5.27)$ & $(5.59)$ & $(1.47)$ & $(1.93)$ & $(0.54)$ \\
\hline
\end{tabular}




\begin{tabular}{cccccccc}
\hline & & $\mathrm{FA} \rightarrow \mathrm{BA}$ & $\mathrm{SA} \rightarrow \mathrm{BA}$ & $\mathrm{FA} \rightarrow \mathrm{SN}$ & $\mathrm{SA} \rightarrow \mathrm{SN}$ & $\mathrm{BA} \rightarrow \mathrm{PI}$ & $\mathrm{SN} \rightarrow \mathrm{PI}$ \\
\hline Japan & Toyota & 0.46 & 0.51 & 0.23 & 0.33 & 0.47 & $0.39^{*}$ \\
& & $(5.98)$ & $(6.61)$ & $(3.77)$ & $(5.35)$ & $(2.49)$ & $(1.14)$ \\
& \multirow{2}{*}{ Sony } & 0.58 & 0.34 & 0.41 & 0.35 & 0.26 & 0.60 \\
& & $(7.65)$ & $(4.73)$ & $(5.01)$ & $(4.39)$ & $(2.14)$ & $(3.52)$ \\
& \multirow{2}{*}{ Mizuno } & 0.55 & 0.42 & 0.41 & 0.25 & 0.42 & $0.44^{*}$ \\
& & $(6.87)$ & $(5.53)$ & $(5.10)$ & $(3.26)$ & $(2.23)$ & $(1.53)$ \\
\hline South & Hyundai & 0.72 & 0.23 & 0.41 & 0.22 & $0.40^{*}$ & $0.42^{*}$ \\
Korea & & $(6.53)$ & $(2.30)$ & $(4.16)$ & $(2.27)$ & $(1.43)$ & $(0.95)$ \\
& \multirow{2}{*}{ Samsung } & 0.73 & 0.23 & 0.46 & 0.32 & 0.53 & $0.36^{*}$ \\
& & $(9.27)$ & $(3.34)$ & $(5.75)$ & $(4.05)$ & $(3.06)$ & $(1.57)$ \\
& \multirow{2}{*}{ Rapido } & 0.52 & 0.43 & 0.31 & 0.38 & 0.50 & $0.38^{*}$ \\
& & $(5.46)$ & $(4.61)$ & $(3.26)$ & $(4.07)$ & $(2.51)$ & $(1.31)$ \\
\hline
\end{tabular}

Note: ${ }^{*}$ represents not significant at 0.05 level. Numbers outside the parentheses represents nonstandard coefficients for path coefficients, and numbers in the parenthese represents nonstandard coefficients for $T$ values.

Table 11 Path coefficient of model 2

\begin{tabular}{llccccc}
\hline & & $\mathrm{FA} \rightarrow \mathrm{BA}$ & $\mathrm{SA} \rightarrow \mathrm{BA}$ & $\mathrm{SA} \rightarrow \mathrm{SN}$ & $\mathrm{BA} \rightarrow \mathrm{PI}$ & $\mathrm{SN} \rightarrow \mathrm{PI}$ \\
\hline \multirow{2}{*}{ USA } & \multirow{2}{*}{ GE } & 0.35 & 0.56 & 0.76 & $0.18^{*}$ & 0.64 \\
& & $(4.09)$ & $(6.26)$ & $(9.90)$ & $(1.51)$ & $(3.97)$ \\
& \multirow{2}{*}{ Motorola } & 0.57 & 0.38 & 0.43 & 0.57 & $0.35^{*}$ \\
& & $(7.43)$ & $(5.15)$ & $(8.51)$ & $(5.86)$ & $(1.72)$ \\
& \multirow{2}{*}{ Nike } & 0.70 & 0.20 & 0.57 & 0.41 & 0.58 \\
& & $(7.79)$ & $(2.38)$ & $(8.51)$ & $(4.82)$ & $(4.23)$ \\
\hline \multirow{2}{*}{ Germany } & \multirow{2}{*}{ Volkswagen } & 0.56 & 0.38 & 0.55 & 0.33 & 0.49 \\
& & $(6.56)$ & $(4.62)$ & $(8.03)$ & $(2.81)$ & $(2.46)$ \\
& \multirow{2}{*}{ Siemens } & 0.49 & 0.46 & 0.63 & 0.48 & 0.47 \\
& & $(6.50)$ & $(6.07)$ & $(11.31)$ & $(4.68)$ & $(3.07)$ \\
& \multirow{2}{*}{ Adidas } & 0.60 & 0.37 & 0.61 & 0.50 & 0.50 \\
& & $(7.55)$ & $(4.96)$ & $(10.99)$ & $(4.95)$ & $(3.27)$ \\
\hline \multirow{2}{*}{ Japan } & 0.44 & 0.51 & 0.61 & 0.31 & 0.58 \\
& \multirow{2}{*}{ Toyota } & $(5.47)$ & $(6.36)$ & $(10.32)$ & $(2.80)$ & $(3.47)$ \\
& \multirow{2}{*}{ Sony } & 0.53 & 0.39 & 0.61 & 0.34 & 0.55 \\
& & $(6.78)$ & $(5.18)$ & $(9.95)$ & $(3.83)$ & $(4.10)$ \\
& \multirow{2}{*}{ Mizuno } & 0.49 & 0.49 & 0.29 & 0.62 & $0.18^{*}$ \\
& $(6.05)$ & $(6.14)$ & $(9.21)$ & $(4.66)$ & $(0.43)$ \\
\hline \multirow{2}{*}{ South Korea } & \multirow{2}{*}{ Hyundai } & 0.66 & 0.28 & 0.60 & 0.34 & 0.52 \\
& & $(5.74)$ & $(2.57)$ & $(8.99)$ & $(2.71)$ & $(2.65)$ \\
& \multirow{2}{*}{ Samsung } & 0.68 & 0.28 & 0.63 & 0.57 & 0.36 \\
& & $(8.34)$ & $(3.76)$ & $(10.77)$ & $(6.00)$ & $(2.64)$ \\
& \multirow{2}{*}{ Rapido } & 0.48 & 0.46 & 0.69 & 0.43 & 0.46 \\
& & $(4.81)$ & $(4.67)$ & $(11.42)$ & $(3.17)$ & $(2.48)$ \\
\hline
\end{tabular}

Note: " represents not significant at 0.05 level. Numbers outside the parentheses represents nonstandard coefficients for path coefficients, and numbers in the parenthese represents nonstandard coefficients for $T$ values. 
Table 12 Path coefficient of model 3

\begin{tabular}{|c|c|c|c|c|c|c|c|c|}
\hline & & $\mathrm{CI} \rightarrow \mathrm{FA}$ & $\mathrm{CI} \rightarrow \mathrm{SA}$ & $\mathrm{FA} \rightarrow \mathrm{BA}$ & $\mathrm{SA} \rightarrow \mathrm{BA}$ & $\mathrm{SA} \rightarrow \mathrm{SN}$ & $\mathrm{BA} \rightarrow \mathrm{PI}$ & $\mathrm{SN} \rightarrow \mathrm{PI}$ \\
\hline \multirow{5}{*}{ USA } & GE & $\begin{array}{c}1.02 \\
(854)\end{array}$ & $\begin{array}{c}0.63 \\
(6.81)\end{array}$ & $\begin{array}{c}0.38 \\
(4.22)\end{array}$ & $\begin{array}{c}0.54 \\
(5.51)\end{array}$ & $\begin{array}{c}0.75 \\
(788)\end{array}$ & 0.19 & $\begin{array}{c}0.64 \\
(3.98)\end{array}$ \\
\hline & \multirow{2}{*}{ Motorola } & $\begin{array}{l}(0.04) \\
1.11\end{array}$ & 0.52 & 0.57 & 0.38 & $\begin{array}{c}(1.00) \\
0.43\end{array}$ & $\begin{array}{c}(1.54) \\
0.56\end{array}$ & $\begin{array}{c}(3.90) \\
0.36\end{array}$ \\
\hline & & (10.03) & (9.34) & (7.11) & $(3.68)$ & (3.34) & $(6.96)$ & $(5.76)$ \\
\hline & \multirow{2}{*}{ Nike } & 1.32 & 0.52 & 0.75 & $0.15^{*}$ & 0.57 & 0.40 & 0.59 \\
\hline & & $(10.93)$ & $(8.89)$ & (6.12) & $(1.40)$ & $(6.19)$ & $(4.27)$ & $(4.56)$ \\
\hline \multirow{6}{*}{ Germany } & \multirow{2}{*}{ Volkswagen } & 0.98 & 0.69 & 0.57 & 0.37 & 0.55 & 0.32 & 0.49 \\
\hline & & (10.13) & (7.94) & (6.39) & $(4.30)$ & $(7.27)$ & $(2.80)$ & (2.48) \\
\hline & \multirow{2}{*}{ Siemens } & 1.01 & 0.70 & 0.50 & 0.45 & 0.63 & 0.47 & 0.48 \\
\hline & & (10.84) & (8.19) & $(6.51)$ & $(5.66)$ & (9.73) & (4.66) & (3.14) \\
\hline & \multirow{2}{*}{ Adidas } & 1.10 & 0.63 & 0.58 & 0.38 & 0.62 & 0.49 & 0.51 \\
\hline & & (8.77) & (7.18) & $(6.83)$ & $(4.87)$ & (9.31) & (4.88) & (3.35) \\
\hline \multirow{5}{*}{ Japan } & \multirow{2}{*}{ Toyota } & 1.05 & 0.61 & 0.44 & 0.50 & 0.61 & 0.29 & 0.60 \\
\hline & & (15.57) & $(9.86)$ & $(5.15)$ & $(6.11)$ & (6.99) & $(3.53)$ & $(8.55)$ \\
\hline & Sony & 1.00 & 0.67 & 0.53 & 0.38 & 0.61 & 0.33 & 0.56 \\
\hline & \multirow[b]{2}{*}{ Mizuno } & (10.31 & 075 & $(0.50)$ & $\begin{array}{c}(4.90) \\
0.48\end{array}$ & (9.34) & (J.) & $021^{*}$ \\
\hline & & $(17.80)$ & $(12.45)$ & $(5.07)$ & (6.68) & $(4.37)$ & (4.94) & $\begin{array}{l}0.21 \\
(1.59)\end{array}$ \\
\hline \multirow{6}{*}{ South Korea } & \multirow{2}{*}{ Hyundai } & 0.99 & 0.76 & 0.66 & 0.27 & 0.60 & 0.33 & 0.53 \\
\hline & & (10.44) & (9.09) & (5.35) & (2.38) & $(8.00)$ & $(2.60)$ & (2.73) \\
\hline & \multirow[t]{2}{*}{ Samsung } & 1.06 & 0.65 & 0.69 & 0.27 & 0.64 & 0.57 & 0.36 \\
\hline & & (11.21) & $(7.91)$ & (7.97) & (3.51) & $(9.06)$ & $(6.04)$ & (2.67) \\
\hline & \multirow[t]{2}{*}{ Rapido } & $\begin{array}{c}0.93 \\
(1036)\end{array}$ & $\begin{array}{c}0.84 \\
(10.03)\end{array}$ & $\begin{array}{c}0.48 \\
(456)\end{array}$ & $\begin{array}{c}0.45 \\
(4.43)\end{array}$ & $\begin{array}{c}0.69 \\
0.04\end{array}$ & 0.43 & $\begin{array}{c}0.47 \\
250)\end{array}$ \\
\hline & & & & & & & & \\
\hline
\end{tabular}

Note: ${ }^{*}$ represents not significant at 0.05 levels. Numbers outside the parentheses represents nonstandard coefficients for path coefficients, and numbers in the parenthese represents nonstandard coefficients for $T$ values.

The results of Table 10-Table 12 show that many of the path coefficients in model 1 are not significant at 0.05 level, especially the paths of brand attitude to purchase intention $(\mathrm{BA} \rightarrow \mathrm{PI})$ and subjective norm to purchase intention $(\mathrm{SN} \rightarrow \mathrm{PI})$, which are quite different from the previous studies. Both Lee and Green (1990) and Chan and Lau (1998) prove the effects of attitude and subjective norm on purchase intention. Thus, we conclude that in spite of good fitness, model 1 is lack of theoretical support. Comparing the path coefficients of model 2 and model 3, they are considered to be similar and stable. Moreover, the fitness of model 3 is better than that of model 2 . Therefore, the explanation power of model is added when country image is introduced into model 2 as a new variable. Hence $\mathrm{H} 1$ and $\mathrm{H} 2$ are both supported.

\section{Conclusion}

\subsection{Discussion}

Data in Table 12 show that country images of the four countries affect product 
functional appraisal and symbolic appraisal of Chinese consumer, and the relationship between country image and product appraisal is positive. These findings are consistent with the prior research. This paper also finds that in 12 models in table 12, the effects of country image on product functional appraisal are greater than the effects of country image on product symbolic appraisal, and the difference is significant at 0.05 levels in Wilcoxon matched pair rank test. The effect of functional appraisal on brand attitude is greater than the effect of symbolic appraisal on brand attitude, and the difference is significant at 0.05 levels. Furthermore, the effect of symbolic appraisal on subjective norm is greater than the effect of functional appraisal on subjective norm, and the difference is significant at 0.05 levels. In these models, it seems that the effect of subjective norm on purchase intention is greater than the effect of brand attitude on purchase intention at most of the time. However, the statistic result shows the difference is not significant in Wilcoxon matched pair rank test. These findings reflect Fishbein's model can be used in Confucian culture context, and the cultural difference can be reflected by path coefficients. Comparing the findings of Western research which prove the effect of attitude on purchase intention is greater than the effect of subjective norm on purchase intention, the findings in this paper are consistent with Lee and Green (1990), and Chan and Lau (1998), whose research are grounded in Asia.

The path coefficients of Model 3 show the effect of symbolic appraisal on purchase intention is greater than the effect of functional appraisal on purchase intention, and the difference is significant at 0.01 in Wilcoxon matched pair rank test. The influences of country image on purchase intention are between $0.44-0.67$, and the difference is not significant in Kruskal-Wallis test. Statistical results can be interpreted as that country image of different countries has no impact on purchase intention. However, the study finds the difference in the effect of country image on purchase intention of different products, and is significant at 0.05 levels in Friedman test. Specifically, the effect of country image on purchase intention of athletic apparels is greater than that of cell phones, and the effect of country image on purchase intention of cars is the lowest. Based on these results, we can find that the effect of country image on purchase intention decreases with the increase of consumer involvement, and the effect of country image on purchase intention of affective products is greater than that of cognitive products.

\subsection{Theoretical implication}

The theoretical implication of this paper is summarized as follows.

First, the study, based on exploratory and confirmatory factor analysis, 
develops country image scale in the Chinese context, and examines Chinese consumers' perception of country image, which can be classified into relationship with China appraisal, degree of country development, general product appraisal, general people appraisal, interactive intention and cultural similarity. These findings can provide examine instruments for further studies of country image.

Second, in this paper, we divide product appraisal into functional product appraisal and symbolic product appraisal. Empirical findings show the effects of country image on functional appraisal is greater than that on symbolic appraisal.

Third, the paper proves that the Fishbein's model has a good cross-cultural adaptability, and there is a strong explanatory power of brand attitude and subjective norm on purchase intention. Comparing these findings with Western research, we find subjective norm has a greater impact on purchase intention, and this reflects the effects of "group consciousness" in Chinese culture on Fishbein's model. Finally, this study finds country image has no direct impact on purchase intention, but it indirectly affects purchase intention through product appraisal, brand attitude, and subjective norm.

\subsection{Managerial implication}

\subsubsection{Implications for overseas companies}

For overseas companies, they should learn how Chinese consumers perceive their country image before entering Chinese market. If Chinese consumers have positive country image perceptions, overseas company can mark the country-of-origin clearly to improve consumer product appraisal, brand attitude and purchase intention. If Chinese consumers have negative perceptions of country image, the company should downplay the country-of-origin image, and establish positive corporate image and brand image to influence consumers' product appraisal, brand attitude and purchase intention.

\subsubsection{Implications for domestic companies}

For domestic companies, they compete with foreign companies not only in domestic market, but also in international market, and they will inevitably encounter problems of country image.

In this study, we have some suggestions to local companies marketing in the domestic market. Because of the effect of country image on product appraisal, domestic companies can use country-of-origin communication strategy of product parts. For instance, when product parts are made in country of favorable image, domestic companies can convey the information to consumers to bring 
out favorable appraisal. Brand name westernization could also be used as a marketing strategy. Brand name westernization means that the brand is named by alphabet and pronunciation of Western language, and can dilute the effect of adverse country image. For example, domestic apparel brands of Metersbonwe, Younger, and Bosideng can attract consumers with greater perception of Western country image. The study also finds the effect of product symbolic appraisal on purchase intention is greater than the effect of product functional appraisal on purchase intention. Therefore, domestic companies should not only improve the function of product and service, but also integrate various marketing resources to improve their products or services' symbolic implications.

We also have some suggestions for domestic companies' marketing in international market. The difference of consumer perception of different countries can result in the difference of consumer product appraisal. Therefore, when making location decisions, company should take into account not only cost and investment policies but also the influence of country image on product appraisal. Much research on country image and country-of-origin has shown when consumers have less information of product, country image will serve as external cue of product appraisal, and when consumers have more information of product, the effect of country image on product appraisal will be lower. Therefore, Chinese companies should enhance product information communication in international marketing.

\subsection{Limitations and further research}

There are several limitations that are inherent in this study. First, in the structural equation model, original values of observations of country image are replaced by factor values, thus in the process of extracting factors, the loss of information is inevitable. Second, the sample comes from the capital city and municipalities. Therefore, the generalizability of the study is limited especially for small and medium-sized cities. Third, south and western regions of China are not involved in the study. Finally, there are also many possible factors that impact purchase intention. However, the study does not control these factors, which may affect the stability of research findings.

Further research is needed to examine the interference effects of involvement, product knowledge, price and familiarity of the country on country image. Additional study may involve consumers in south China and western regions. Another area where future study is needed lies in identifying the impact of large-scale cases, such as the 2008 Beijing Olympic Games, on China's country image.

Acknowledgments The work is supported by the National Natural Science Foundation of China (No. 70672033). The author wish to thank Wu Ruijuan, a doctoral student of school of 
business, Nankai University, for her excellent work in translating this paper.

\section{References}

Al-Sulaiti K I, Baker M J (1998). Country of origin effects: A literature review. Marketing Intelligence \& Planning, 16(3): 150-169

Ajzen I, Fishbein M (1980). Understanding Attitudes and Predicting Social Behavior. NJ: Prentice-Hall Englewood Cliffs

Baker M, Ballington L (2002). Country of origin as a source of competitive advantage. Journal of Strategic Marketing, 10(2): 157-168

Bilkey W J, Nes E (1982). Country-of-origin effects on product evaluations. Journal of International Business Studies, 13: 89-99

Chao P (1993). Partitioning country of origin effects: Consumer evaluations of a hybrid product. Journal of International Business Studies, 24(2): 291-306

Chan R Y, Lau L (1998). A test of the Fishbein-Ajzen behavioral intentions model under Chinese cultural settings: Are there any differences between PRC and Hong Kong consumers? Journal of Marketing Practice: Applied Marketing Science, 4(3): 85-101

Erickson G M, Johansson J K, Paul C (1984). Image variables in multi-attribute product evaluations: Country-of-origin effect. Journal of Consumer Research, 11: 694-699

Fishbein M, Ajzen I (1975). Belief, Attitude, Intention, and Behavior: An Introduction to Theory and Research. Mass: Addison-Wesley

Fornell C, Larcker D F (1981). Structural equation model with unobservable variables and measurement error: Algebra and statistics. Journal of Marketing Research, 18(3): 382-389

Hair J F, Anderson R E, Tatham R L, Black W C (1998). Multivariate Date Analysis. NJ: Prentice Hall.

Han C M (1989). Country image: Halo or summary construct? Journal of Marketing Research, 26(2): 222-229

Han C M, Terpstra V (1988). Country of origin effects for uni-national and bi-national Products. Journal of International Business Studies, 19(2): 235-255

Heider F (1958). The Psychology of Interpersonal Relations. New York: Wiley

Hu L, Bentle P M (1998). Fit indices in covariance structure modeling: Sensitivity to underparameterized model misspecification. Psychological Method, 3(4): 424-453

Johansson J K, Ronkainen I A, Czinkota M R (1994). Negative country-of-origin effects: The case of the new Russia. Journal of International Business Studies, 25(1): 156-176

Klein J G, Ettenson R, Morris M D (1998). The animosity model of foreign product purchase: An empirical test in the People's Republic of China. Journal of Marketing, 62(1): 89-100

Krishnakumar P (1974). An exploratory study of influence of country of origin on the product images of persons from selected countries. University of Florida, Gainesville

Laroche M, Papadopoulos N, Heslop L, Mourali M (2005). The influence of country image structure on consumer evaluations of foreign products. International Marketing Review, 22(1): 96-115

Lee C (1990). Modifying an American consumer behavior model for consumers in Confucian culture: The case of Fishbein behavioral intention model. Journal of International Consumer Marketing, 3(1): 27-50

Lee C, Green R T (1990). Cross-cultural examination of the Fishbein behavioral intentions model. Journal of International Business Study, 22(2): 289-305 
Lee D, Gopala G (1999). Effects of partitioned country image in the context of brand image and familiarity: A categorization theory perspective. International Marketing Review, 16(1): 18-39

Li Z G, Murray L W, Scott D (2000). Global sourcing, multiple country-of-origin facets, and consumer reactions. Journal of Business Research, 47(2): 121-133

Martin I, Eroglu S (1993). Measuring a multi-dimensional construct: Country image. Journal of Business Research, 28: 191-210

Nagashima A (1970). A comparison of Japanese and U.S. attitudes toward foreign products. Journal of Marketing, 34(1): 68-74

Nagashima A (1977). A comparative 'Made In' product image survey among Japanese businessmen. Journal of Marketing, (July): 95-100

Parameswaran R, Pisharodi R M (1994). Facts of country image: An empirical assessment. Journal of Advertising, 23(March): 43-61

Papadopoulos N, Heslop L (2000). Country as brand: Canadian products abroad. Ivey Business Journal, (Nov/Dec): 30-36

Petty R, Cacioppo J T (1986). The elaboration likelihood model of persuasion. Advances in Hydroscience, 19: 124-205

Roth M S, Romeo J B (1992). Matching product category and country image perceptions: A framework for managing country-of-origin effects. Journal of International Business Studies, (Third Quarter): 477-497

Schooler R D (1965). Product bias in the central American common market. Journal of Marketing Research, (November): 394-397

安钟石, 吴静芳 (Ahn Jongseok, Wu Jingfang) (2003). 中国内需市场上国家形象对消费者购买行 为的影响 (Country image and its impact on consumer behavior in China: A case of C-TV product). In: 21世纪的中国市场——理解与探索 (Unscrambling and Exploring the Chinese Market in 21 Century). 北京: 经济科学出版社: 79-108

陈丰富 (Chen Fengfu) (2004). 来源国形象对产品购买意向的影响 (The Influence of country image on product purchase intention). 台湾: 国立成功大学企业管理学系EMBA论文, 55-96

陈俊郎 (Chen Junlang) (2001). 国家形象效果对产品评估与购买决策之影响 (The influence of country image on product evaluation and purchase decision). 台北: 铭传大学企业管理研究所 论文, 52-65

侯杰泰, 温忠麟, 成子娟 (Hou Jietai, Wen Zhonglin, Cheng Zijuan) (2004). 结构方程模型及其 应用 (Structural Equation Model and its Application). 北京: 教育科学出版社, 166-176

田圣炳, 陈启杰 (Tian Shengbing, Chen Qijie) (2004). 国际化经营中的原产地形象研究综述 (Review of the study of "country-of-origin" phenomenon in business internationalization). 国外经济与管理, 26(8): 25-29

易中天 (Yi Zhongtian) (1995). 中国文化现象解密 (A Probe into Chinese Culture). 海口: 海南 出版社, 101

尹盛焕 (Yin Shenghuan). (2006). 韩国消费者对中国冰箱选择的研究 (A study on the Korean consumers' selection of Chinese refrigerators). 北京城市学院学报, (2): 57-73

Appendix

Appendix 1 Measurement items of country image

\begin{tabular}{ccl}
\hline Dimensions & Code & \multicolumn{1}{c}{ Measurement items } \\
\hline General country attributes & A11 & Affluent \\
& A12 & Economically developed \\
& A13 & High living standard \\
\hline
\end{tabular}

(To be continued) 
(Continued)

\begin{tabular}{cll}
\hline Dimensions & Code & \multicolumn{1}{c}{ Measurement items } \\
\hline General country attributes & A14 & Advanced technology \\
& A15 & Good condition of life \\
A16 & High level of education \\
& A17 & Cultural similarity \\
A18 & Attracting in culture and funny \\
& A19 & Democratic \\
& A110 & High level of participation on international issues \\
& A111 & Peace-loving \\
& A112 & Friendly to us \\
& A113 & Cooperative to us \\
& A114 & Favorable impression \\
& A21 & Amiable and kind \\
A22 & High level of education \\
& A23 & Extraordinary \\
& A24 & Creative \\
A25 & Diligent and honest \\
& A26 & Trustful \\
A27 & Integrity \\
& A28 & Literacy \\
& A29 & Considerate \\
& A210 & Feel to close \\
& A211 & A good impression \\
& A31 & High quality \\
A32 & Global prestigious \\
& A33 & Technically advanced \\
& A34 & Durable \\
A35 & Well-designed \\
& A36 & Good after- sale service \\
A37 & Desirable products \\
\hline &
\end{tabular}

Appendix 2 Measurement items of functional appraisal

\begin{tabular}{ccl}
\hline Latent variables & Code & \multicolumn{1}{c}{ Measurement items } \\
\hline Product functional appraisal & B11 & High quality \\
& B12 & Advanced technology \\
& B13 & Well-designed \\
B14 & Good after-sale service \\
& B15 & Feel good (car) \\
B16 & Sound good (cell phone) \\
& B17 & Touch good (apparel) \\
\hline
\end{tabular}


Appendix 3 Measurement items of symbolic appraisal

\begin{tabular}{ccl}
\hline Latent variables & Code & \multicolumn{1}{c}{ Measurement items } \\
\hline Product symbolic appraisal & B21 & Very refined \\
& B22 & High standing \\
& B23 & Smart \\
B24 & Affluent \\
& B25 & Ambitious \\
& B26 & Creative \\
& B27 & International sighted \\
\hline
\end{tabular}

Appendix 4 Measurement items of brand attitude

\begin{tabular}{ccll}
\hline Latent variable & Code & Measurement items \\
\hline Brand attitude & C1 & Good & \\
& C2 & Nice and funny \\
\hline
\end{tabular}

Appendix 5 Measurement items of subjective norm

When you want to buy , your relatives and friends think

\begin{tabular}{ccc}
\hline Latent variable & Code & Measurement item \\
\hline Subjective norm & D & Of course you should buy \\
\hline
\end{tabular}

Appendix 6 Measurement items of purchase intention

\begin{tabular}{ccl}
\hline Latent variable & Code & \multicolumn{1}{c}{ Measurement items } \\
\hline Purchase intention & E1 & Intent to bug \\
& E2 & Likely to buy \\
& E3 & Preferred choice if other things are equal \\
\hline
\end{tabular}

